\title{
Risk Governance and Performance: Evidence From Eurozone's Large Banks
}

\author{
Paolo Agnese $^{1,2} \&$ Paolo Capuano ${ }^{3}$ \\ ${ }^{1}$ LUMSA University, Rome, Italy \\ ${ }^{2}$ UNINETTUNO University, Rome, Italy \\ ${ }^{3}$ SAPIENZA University, Rome, Italy \\ Correspondence: Paolo Agnese, UNINETTUNO University, Rome, Italy.
}

Received: July 28, 2020

doi:10.5430/ijfr.v11n5p28
Accepted: September 4, 2020

Online Published: September 21, 2020

\begin{abstract}
In this paper, by means of econometric models, we investigate the relationship between risk governance and performance of the Eurozone's Global Systemically Important Banks (G-SIBs), over the period 2014-2018. The results of the quantitative analysis show that the choice to appoint a Chief Risk Officer (CRO) can be useful to shrink the bank risk-taking. Furthermore, we find that the importance attributed by the bank to the CRO - in terms of membership of the executive committee and in terms of remuneration - is positively correlated to both profitability and bank risk-taking. In addition, the analysis shows that the activity carried out by the Risk committee can be helpful to break down the risks.
\end{abstract}

Keywords: banks, corporate governance, risk management, risk governance, performance

JEL codes: G21, G32, G34

\section{Introduction}

The field of research covered by this paper is that which, in the sphere of the broader topic of corporate governance, concerns the study of the relationship between risk governance and performance of banks.

Corporate governance is considered as the set of relationships between management, the board of directors, shareholders and other stakeholders. It establishes the objectives and determines the means to achieve them and to monitor corporate performance (OECD 2003).

Instead, the concept of risk governance is intended as the framework through which the board of directors and top management establish the overall strategy and risk of the company, which should be adequately identified, measured and managed (FSB 2013).

This paper analyzes the relationship between various risk governance variables and some bank performance variables, in order to highlight the possible connections. The risk governance variables examined are the following: CRO Present; CRO Executive; CRO Top 5; CRO Centrality; Risk Committee Experience; Active Risk Committee; Board Independence. While the bank performance ratios used are the following: return on average equity (ROAE); return on average assets (ROAA); risk-adjusted return on average equity (RAROAE); risk-adjusted return on average assets (RAROAA). In addition, we also consider the Z-score ratio, which represents a synthetic measure of the degree of corporate solvency.

The literature on the subject mainly uses data relating to the US banking system. In this study, using multiple linear and log-linear regression models, we analyze how specific risk governance variables are able to influence the performance of Eurozone's Global Systemically Important Banks (G-SIBs), from 2014 to 2018. It is a sample of banks little explored even by the most recent literature.

The paper is structured as follows. Section 2 presents a literature review on the concerned topic. Section 3 describes the methodology and the multiple regression models adopted in the analysis. Section 4 presents the empirical results. Lastly, Section 5 concludes the paper. 


\section{Related Literature}

The academic literature that analysed the relationship between risk governance and bank performance is rather sparse.

Part of the literature on risk governance highlights the need for the presence of a collegial body (Risk committee) within the board of directors, in relation to its support for risk management at group level. Not only, this literature also stresses the importance of the designation of a specific subject, the Chief Risk Officer (CRO), in charge of supervising all the bank risks, as well as keeping the board constantly informed on the matter.

With reference to the relevance of the activities carried out by the Risk committee and the CRO, the analysis carried out by Mongiardino and Plath (2010), for example, identifies some best risk governance practices, stressing the importance of an independent and authoritative Risk committee set up within the board of directors, as well as the establishment of the CRO as a member of the bank's executive committee. Furthermore, according to these authors, the CRO should report to both the CEO and the board. Similarly, Lingel and Sheedy (2012) argue that some risk governance variables are particularly important in determining the risk profile of banks. In particular, this concerns the inclusion of the CRO in the senior executive team, the remuneration of the CRO (ranked in the Top 5 paid managers), the activity carried out by the Risk committee, as well as the percentage of members of the Risk committee with professional experience in the financial sector. More recently, Dupire and Slagmulder (2019) prove that European financial institutions with powerful owners are negatively associated with CRO and Risk committee presence. While institutions with state control and higher board independence have more independent Risk committees.

With specific reference to the presence of the CRO, Aebi et al. (2012) show that banks in which the CRO directly reports to the board of directors, rather than directly to the CEO, outperform their competitors in terms of stock returns and ROE during the financial crisis of 2007-2008. Furthermore, Dong et al. (2014), relative to the Chinese banking system, report that the presence of CRO on the executive team significantly reduces bank risk-taking.

With specific regard instead to the relevance of the Risk committee, Battaglia and Gallo (2015), analyzing a sample of Chinese and Indian listed banks over the period 2007-2011, find that banks with larger Risk committee perform better in terms of profitability (ROE and ROA). However, they argue that the evaluation of banks expressed by the market is negatively associated with the size of the Risk committee, as well as positively associated with the number of the Risk committee' meetings.

A peculiar aspect concerning risk governance, often analysed from the literature following the outbreak of the international financial crisis, is about the relationship between independence of the members of the board of directors and the level of bank profitability and risk. However, the studies conducted on this issue have not always found a point of agreement.

Pathan and Faff (2013), using a broad panel of large US bank holding companies over the period 1997-2011, demonstrate that both size and independence of the board have a negative impact on bank performance. Similarly, Erkens et al. (2012) prove that financial firms with a higher percentage of independent boards and higher institutional ownership experienced worse stock returns during the global financial crisis of 2007-2008. However, Adams and Mehran (2012), analyzing the relationship between board structure and performance of a sample of banking firm data that spans 34 years, find that board independence is not related to performance, although board size is positively related to performance. A dissenting argument is provided by the recent research of Harkin et al. (2020). Using data for UK banks over the period 2003-2012, they find that independence in the governance structure affects both risk and return.

With reference to the bank risk-taking, Pathan (2009), using a sample of large US bank holding companies over 1997-2004, shows that there is a negative correlation between the independence of the board and the overall riskiness of the bank. In fact, the greater the percentage of total directors who are independent, the lower the bank risk-taking. Similarly, Brandão-Marques and Oppers (2014), analyzing data from major banks of various advanced and emerging market economies (where about 50 percent of the banks are from the U.S.), find that independence at board level leads to reduced risk. Also the research of Battaglia and Gallo (2017) comes to similar conclusions. Analyzing a sample of European banks during the crisis, they show that banks with more independent directors had a lower probability of default during the crisis.

Always with reference to the independence of the board of directors, Minton et al. (2014) examine how the presence of financial experts among independent directors relates to risk taking and performance of U.S. banks during the 
period from 2003 to 2008 . They find that the level of financial expertise among independent directors is positively related to risk taking at the onset of the financial crisis.

\section{Variables and Econometric Models}

In this section, first we describe the variables of models (dependent variables, key independent variables and control variables) and then we focus on models structure implemented.

In particular, for purposes of the regression analysis, we have classified the variables into the following categories:

- independent variables: risk governance variables (key independent variables) and control variables;

- dependent variables: performance variables.

The key independent variables, in turn, have been divided into the following categories:

- variables that measure the relevance of the person responsible for risk management (CRO Present, CRO Executive, CRO Top 5, CRO Centrality);

- variables that measure the quality of the bank's overall risk monitoring carried out by the board (Risk Committee Experience, Active Risk Committee, Board Independence).

In particular, CRO Present represents a dichotomous variable that assumes a value of one if the bank has the figure of the CRO and zero otherwise.

The CRO Executive variable, also dichotomous, is equal to one if the CRO is a member of the executive committee, while it is equal to zero in the opposite case. In the event that it assumes a value of one, it is implicitly assumed that the CRO has a significant influence and authoritativeness in the overall risk management, compared to the opposite case.

On this issue, Aebi et al. (2012) show that banks in which the CRO reports directly to the board, rather than to the CEO, performed better during the financial crisis of 2007-2008.

CRO Top 5 represents a dummy variable that assumes a value of one if the remuneration of the CRO is among the top five highest considering the top managers, otherwise it assumes a value of zero.

The CRO Centrality variable, equal to the ratio between the remuneration of the CRO and that of the CEO, represents a proxy of the importance attributed by the bank to the role of the CRO in the management of corporate risks. This variable is zero in the absence of the CRO.

As indicated above, the second category of risk governance measures aims to assess the ability of the board of directors to oversee the management of bank risks. This control activity is assessed, first of all, through some variables that measure the quality of the activity carried out by the Risk committee, which is responsible for monitoring and controlling the bank's overall risk.

The Risk Committee Experience variable measures the quality and professional experience of the members of the Risk committee in the financial sector (Aebi et al. 2012; Dupire and Slagmulder 2019; Ellul and Yerramilli 2013). It is expressed by the percentage of directors who have had professional experience with companies operating in the financial sector, compared to the total of its members. The underlying hypothesis considered is that an efficient Risk committee is composed of members with adequate professional banking experience.

The Active Risk Committee variable measures the degree of activity of the Risk committee. The number of meetings held by the latter in the reference year was considered (Aebi et al. 2012; Ellul and Yerramilli 2013; Lingel and Sheedy 2012). Risk supervision, in fact, implies the need to guarantee constant monitoring of the same, as well as adequate and timely adjustment actions aimed at containing risks.

The Board Independence variable indicates the percentage of independent members of the board of directors. The inclusion of this variable in the regression models can help to understand if the boards of directors formed by independent members play a significant role in the process of determining the bank's profitability and risk.

With reference, however, to the dependent variables analysed, in order to measure the bank's performance, the following four indicators are considered: return on average equity (ROAE); return on average assets (ROAA); risk-adjusted return on average equity (RAROAE), expressed as the ratio between the ROAE and its standard deviation; risk-adjusted return on average assets (RAROAA), equal to the ratio between the value of the ROAA and its standard deviation. As known, the RAROAE and RAROAA indicators are risk-adjusted performance measures. As mentioned, we consider them equal to the relationship between the reference indicator (respectively, the ROAE and the ROAA) and its standard deviation (Stiroh 2004; Stiroh and Rumble 2006). They have been included in the 
models because ROAE and ROAA are non-risk sensitive ratios: they do not take into account the risk assumed by the bank.

To measure the risk appetite of each bank analysed, however, the Z-score indicator is also considered. It represents a summary measure of the degree of corporate solvency (Boyd and Graham 1986; Boyd et al. 1993; Laeven and Levine 2009; Stiroh 2004). Specifically, it defines the bank's insolvency as the state in which the overall loss is greater than the equity value. In this case, the Z-score represents a particular non-linear transformation of the bank's probability of default. It can be analytically expressed as:

$$
\text { Z-score }=[\text { ROAA }+(\mathrm{E} / \mathrm{A})] / \sigma(\mathrm{ROAA})
$$

where:

$\mathrm{A}=$ total asset;

$\mathrm{E}=$ equity;

$\sigma($ ROAA $)=$ standard deviation of ROAA .

The Z-score variable is therefore a risk indicator. It is equal to the inverse of insolvency probability: high value of the Z-score indicates a low probability of bank default, and vice versa.

To verify the robustness of the relationship between the variables analysed, some control variables have been included within the regression models. These are variables that do not directly affect the subject of the analysis. Nevertheless, they contribute to ensuring that the error term is unrelated to the dependent variable. This is because they are correlated with the independent variables.

Specifically, the control variables taken into consideration are the following: Bank Size (Note 1); NPL ratio; Tier 1 ratio; Total Capital ratio; Equity to Assets ratio; Net Interest Margin; Cost to Income ratio; Interbank ratio; Loans to Assets ratio; Loans to Deposits ratio; Liquid Assets to Deposits ratio.

All the variables considered in this paper are analysed through multiple regression models. In particular, we utilize the multiple linear model and the fixed effects model. For each model, the logarithm of the dependent variable is also considered.

The underlying hypothesis is that there may be a significant relationship, of a linear or non-linear type, between independent and dependent variables.

The pooled OLS is the linear model used. It's expressed as follows:

$$
\mathrm{Y}_{\mathrm{j}, \mathrm{t}}=\alpha+\sum_{\mathrm{m} 1} \beta_{\mathrm{m} 1} * \mathrm{RG}_{\mathrm{j}, \mathrm{t}, \mathrm{m} 1}+\sum_{\mathrm{m} 2} \beta_{\mathrm{m} 2} * \mathrm{X}_{\mathrm{j}, \mathrm{t}, \mathrm{m} 2}+\mathrm{u}_{\mathrm{j}, \mathrm{t}}
$$

where:

$\mathrm{j}=1, \ldots, 7$, is the cross section entity (bank);

$\mathrm{m} 1=1, \ldots, \mathrm{k}$;

$\mathrm{m} 2=\mathrm{k}+1, \ldots, \mathrm{M}$;

$\mathrm{t}=2014, \ldots, 2018$;

$\mathrm{Y}_{\mathrm{j}, \mathrm{t}}$ represents the performance variables for the $\mathrm{j}$-th entity and $\mathrm{t}$-th year;

$\alpha$ is the intercept in the regression function;

$\mathrm{RG}_{\mathrm{j}, \mathrm{t}, \mathrm{ml}}$ represents the $\mathrm{k}$ risk governance variables for the $\mathrm{j}$-th entity and $\mathrm{t}$-th year;

$\mathrm{X}_{\mathrm{j}, \mathrm{t}, \mathrm{m} 2}$ represents the $\mathrm{M}-\mathrm{k}$ control variables for the $\mathrm{j}$-th entity and $\mathrm{t}$-th year;

$\beta_{\mathrm{m} 1}$ is the regression coefficient for the $\mathrm{k}$ risk governance variables;

$\beta_{\mathrm{m} 2}$ is the regression coefficient for the M-k control variables;

$\mathrm{u}_{\mathrm{j}, \mathrm{t}}$ is the error term for the $\mathrm{j}$-th entity and $\mathrm{t}$-th year.

In addition, the regression model on panel data with fixed individual effects is used. It allows to consider the internal variability of each entity (bank). In fact, this model includes the heterogeneity of the analysis units. For example, there may be differences between country and country in the performance of banks, in the levels of interest rates, in the prices of real estate markets. There may also be differences between bank and bank regarding the management skills, the scale, the location, or the industry exposure that affect both diversification choices and bank performance (Stiroh and Rumble 2006). These unobserved differences are therefore covered by the fixed effects model. 
Therefore, the equation of the second regression model (fixed effects model) is as follows:

$$
\mathrm{Y}_{\mathrm{j}, \mathrm{t}}=\alpha_{\mathrm{j}}+\sum_{\mathrm{m} 1} \beta_{\mathrm{m} 1} * \mathrm{RG}_{\mathrm{j}, \mathrm{tm} 1}+\sum_{\mathrm{m} 2} \beta_{\mathrm{m} 2} * \mathrm{X}_{\mathrm{j}, \mathrm{m} 2}+\mathrm{s}_{\mathrm{j}}+\lambda_{\mathrm{j}, \mathrm{t}}
$$

where:

$\mathrm{j}=1, \ldots, 7$, is the cross section entity (bank);

$\mathrm{m} 1=1, \ldots, \mathrm{k}$;

$\mathrm{m} 2=\mathrm{k}+1, \ldots, \mathrm{M}$;

$\mathrm{t}=2014, \ldots, 2018$;

$\mathrm{Y}_{\mathrm{j}, \mathrm{t}}$ represents the performance variables for the $\mathrm{j}$-th entity and $\mathrm{t}$-th year;

$\alpha_{\mathrm{j}}$ is the intercept for the $\mathrm{j}$-th entity;

$\mathrm{RG}_{\mathrm{j}, \mathrm{t}, \mathrm{ml}}$ represents the $\mathrm{k}$ risk governance variables for the $\mathrm{j}$-th entity and $\mathrm{t}$-th year;

$\mathrm{X}_{\mathrm{j}, \mathrm{t}, \mathrm{m} 2}$ represents the $\mathrm{M}-\mathrm{k}$ control variables for the $\mathrm{j}$-th entity and $\mathrm{t}$-th year;

$\beta_{\mathrm{m} 1}$ is the regression coefficient for the $\mathrm{k}$ risk governance variables;

$\beta_{\mathrm{m} 2}$ is the regression coefficient for the M-k control variables;

$\mathrm{s}_{\mathrm{j}}$ is the individual-specific error component for $\mathrm{j}$-th entity, constant over time;

$\lambda_{\mathrm{j}, \mathrm{t}}$ is the remaining random error component for the $\mathrm{j}$-th entity and the $\mathrm{t}$-th year.

For both econometric models, the corresponding log-linear model is also examined. It considers the logarithm of the dependent variable.

In summary, the statistical models used relate the dependent variables (profitability and risk) and the independent variables (risk governance) of the reference banks, in order to assess their type and strength of dependence.

Furthermore, the models consider some dimensional control variables. This in order to take into account some characteristics of the balance sheet (total assets, equity, deposits, loans, etc.), as well as certain economic variables (interest margin, cost income ratio, etc.) of the banks analysed.

\section{Empirical Results}

The data are collected using a variety of sources, including Moody's Analytics BankFocus database, annual bank reports, corporate governance reports, remuneration reports and company websites. In particular, the Eurozone's Global Systemically Important Banks (G-SIBs) are taken into consideration, over the period 2014-2018 (Note 2).

We consider a recent and short period characterized by moderate dynamics compared to the high financial turmoil caused by the crisis that started in 2007. This in order to obtain results not distorted by the international financial crisis. Furthermore, this period has not been analysed by previous studies and allows to avoid the difficulties in examining the evolution of institutions over longer periods of time.

Moving on to data analysis, the matrix of correlations between the variables examined (Table 1) includes more variables than those considered in the regression models (Tables 2 to 6). Some variables, in fact, have not been considered because their correlation with other variables included in the model is very high. Their inclusion would lead to collinearity problems.

In particular, Table 1 shows high degree of correlation between the Tier 1 ratio and Total Capital ratio variables. This is because Tier 1 constitutes the best part of Total Capital. Therefore, including both variables in the regression models would lead to undesired redundancy due to distortions on the regression coefficients. Furthermore, it should be noted that the liquidity variables considered (Interbank ratio, Net Loans/Total Assets, Net Loans/Deposits, Liquid Assets/Deposits) also have a strong correlation (Note 3). Consequently, in order to overcome this limitation, only the variables that include the deposits are considered in the statistical analysis. 
Table 1. Correlation matrix

\begin{tabular}{|c|c|c|c|c|c|c|c|c|c|c|c|c|c|c|c|c|c|c|c|c|c|c|c|}
\hline & $\begin{array}{r}\text { CRO } \\
\text { Pres } \\
\text { ent }\end{array}$ & $\begin{array}{c}\text { CRO } \\
\text { Execu } \\
\text { tive }\end{array}$ & $\begin{array}{l}\text { CRO } \\
\text { Top5 }\end{array}$ & $\begin{array}{l}\text { CRO } \\
\text { Centr } \\
\text { ality }\end{array}$ & $\begin{array}{c}\text { RiskC } \\
\text { omEx } \\
\text { perien } \\
\text { ce }\end{array}$ & $\begin{array}{c}\text { Active } \\
\text { RiskC } \\
\text { om. }\end{array}$ & $\begin{array}{l}\text { Board } \\
\text { Indep. }\end{array}$ & $\begin{array}{r}\text { Bank } \\
\text { Size }\end{array}$ & $\begin{array}{l}\text { NPL } \\
\text { ratio }\end{array}$ & $\begin{array}{l}\text { Tier } 1 \\
\text { ratio }\end{array}$ & $\begin{array}{c}\text { Total } \\
\text { Capit } \\
\text { al } \\
\text { ratio }\end{array}$ & $\begin{array}{c}\text { Equity } \\
\quad / \\
\text { Assets }\end{array}$ & $\begin{array}{c}\text { Net } \\
\text { Inter. } \\
\text { Margi } \\
\text { n }\end{array}$ & $\begin{array}{c}\text { ROA } \\
\text { A }\end{array}$ & $\begin{array}{c}\text { ROA } \\
\text { E }\end{array}$ & $\begin{array}{c}\text { Cost to } \\
\text { Income } \\
\text { ratio }\end{array}$ & $\begin{array}{c}\text { Interb } \\
\text { ankra } \\
\text { tio }\end{array}$ & $\begin{array}{l}\text { Loans/ } \\
\text { Assets }\end{array}$ & $\begin{array}{c}\text { Loans } \\
/ \\
\text { Depos } \\
\text { its }\end{array}$ & $\begin{array}{c}\text { Liq. } \\
\text { Assets } \\
, \\
\text { Depos } \\
\text { its }\end{array}$ & $\begin{array}{c}\text { RARO } \\
\text { AA }\end{array}$ & $\begin{array}{l}\text { RAR } \\
\text { OAE }\end{array}$ & Z-SCORE \\
\hline CROPresent & 1 & 0,49 & 0,24 & 0,66 & 0,36 & 0,1 & 0,46 & 0,42 & 0,1 & $-0,15$ & $-0,19$ & 0,01 & 0,09 & $-0,03$ & $-0,05$ & 0,13 & $-0,06$ & 0,06 & $-0,08$ & 0,08 & 0,01 & 0,01 & $-0,1$ \\
\hline CRO Executive & & 1 & 0,49 & 0,31 & 0,03 & $-0,81$ & 0,63 & 0,05 & 0,13 & 0,27 & 0,26 & $-0,63$ & $-0,76$ & $-0,31$ & $-0,19$ & 0,47 & 0,34 & $-0,29$ & $-0,47$ & 0,33 & 0,02 & 0,02 & $-0,8$ \\
\hline CRO Top5 & & & 1 & 0,46 & 0,01 & $-0,42$ & 0,21 & $-0,5$ & $-0,1$ & 0,41 & 0,48 & $-0,22$ & $-0,26$ & $-0,27$ & $-0,25$ & 0,36 & 0,45 & 0,22 & 0,13 & $-0,16$ & $-0,05$ & $-0,08$ & $-0,48$ \\
\hline CROCentrality & & & & 1 & 0,32 & $\mathbf{0}$ & 0,24 & 0,2 & $-0,33$ & 0,11 & 0,01 & $-0,03$ & 0,16 & 0,06 & 0,04 & 0,12 & 0,21 & 0,15 & 0,12 & $-0,08$ & 0,06 & 0,06 & $-0,11$ \\
\hline $\begin{array}{l}\text { RiskCom. } \\
\text { Experience }\end{array}$ & & & & & 1 & 0,19 & 0,26 & 0,46 & 0,2 & $-0,35$ & $-0,36$ & 0,08 & 0,23 & $-0,1$ & $-0,15$ & 0,18 & $-0,2$ & 0,06 & $-0,07$ & $-0,1$ & 0,02 & $\mathbf{0}$ & $-0,18$ \\
\hline $\begin{array}{l}\text { Active } \\
\text { RiskCom. }\end{array}$ & & & & & & 1 & $-0,42$ & 0,21 & $-0,01$ & $-0,44$ & $-0,45$ & 0,74 & 0,9 & 0,31 & 0,16 & $-0,43$ & $-0,48$ & 0,35 & 0,46 & $-0,29$ & $-0,01$ & $-0,02$ & 0,85 \\
\hline Board Indep. & & & & & & & 1 & 0,3 & $-0,16$ & 0,16 & 0,2 & $-0,46$ & $-0,37$ & $-0,04$ & 0,05 & 0,23 & 0,28 & $-0,09$ & $-0,33$ & 0,18 & 0,11 & 0,11 & $-0,45$ \\
\hline Bank Size & & & & & & & & 1 & $-0,06$ & $-0,49$ & $-0,55$ & $-0,17$ & 0,09 & $-0,02$ & $-0,04$ & 0,19 & $-0,36$ & $-0,4$ & $-0,5$ & 0,35 & $-0,02$ & 0,01 & 0 \\
\hline NPL ratio & & & & & & & & & 1 & $-0,53$ & $-0,5$ & 0,25 & 0 & $-0,3$ & $-0,32$ & 0,05 & $-0,27$ & 0,14 & 0,11 & $-0,25$ & $-0,11$ & $-0,14$ & $-0,28$ \\
\hline Tier 1 ratio & & & & & & & & & & 1 & 0,96 & $-0,13$ & $-0,4$ & 0,36 & 0,42 & $-0,09$ & 0,37 & $-0,05$ & $-0,07$ & 0,2 & 0,41 & 0,42 & $-0,1$ \\
\hline $\begin{array}{l}\text { Total Capital } \\
\text { ratio }\end{array}$ & & & & & & & & & & & 1 & $-0,2$ & $-0,42$ & 0,24 & 0,31 & $-0,01$ & 0,41 & $-0,03$ & $-0,06$ & 0,17 & 0,31 & 0,31 & $-0,12$ \\
\hline $\begin{array}{l}\text { Equity/Total } \\
\text { Assets }\end{array}$ & & & & & & & & & & & & 1 & 0,77 & 0,48 & 0,32 & $-0,56$ & $-0,44$ & 0,54 & 0,64 & $-0,5$ & 0,29 & 0,26 & 0,63 \\
\hline $\begin{array}{l}\text { Net } \\
\text { InterestMargin }\end{array}$ & & & & & & & & & & & & & 1 & 0,41 & 0,27 & $-0,57$ & $-0,26$ & 0,65 & 0,7 & $-0,61$ & 0,04 & 0,04 & 0,72 \\
\hline ROAA & & & & & & & & & & & & & & 1 & 0,98 & $-0,8$ & 0,07 & 0,4 & 0,38 & $-0,27$ & 0,79 & 0,81 & 0,45 \\
\hline ROAE & & & & & & & & & & & & & & & 1 & $-0,78$ & 0,21 & 0,36 & 0,32 & $-0,24$ & 0,76 & 0,8 & 0,34 \\
\hline $\begin{array}{l}\text { Cost to Income } \\
\text { ratio }\end{array}$ & & & & & & & & & & & & & & & & 1 & $-0,16$ & $-0,67$ & $-0,68$ & 0,57 & $-0,36$ & $-0,38$ & $-0,6$ \\
\hline Interbank ratio & & & & & & & & & & & & & & & & & 1 & 0,32 & 0,26 & $-0,28$ & $\mathbf{0}$ & 0,02 & $-0,28$ \\
\hline $\begin{array}{l}\text { Loans/Total } \\
\text { Assets }\end{array}$ & & & & & & & & & & & & & & & & & & 1 & 0,91 & $-0,9$ & 0,11 & 0,1 & 0,27 \\
\hline Loans/Deposits & & & & & & & & & & & & & & & & & & & 1 & $-0,84$ & 0,07 & 0,06 & 0,45 \\
\hline $\begin{array}{l}\text { Liq. } \\
\text { Assets/Deposits }\end{array}$ & & & & & & & & & & & & & & & & & & & & 1 & $-0,06$ & $-0,04$ & $-0,17$ \\
\hline RAROAA & & & & & & & & & & & & & & & & & & & & & 1 & 1 & $-0,02$ \\
\hline RAROAE & & & & & & & & & & & & & & & & & & & & & & 1 & $-0,01$ \\
\hline Z-SCORE & & & & & & & & & & & & & & & & & & & & & & & 1 \\
\hline
\end{tabular}

The table shows the matrix of correlations between the variables examined (performance variables, risk governance variables and control variables). It includes more variables than those considered in the regression models: "Interbank ratio" and "Net loans/total assets" have not been considered. This because their correlation with other variables included in the model is very high.

It's also useful to keep in mind that both the sample of the banks and the timespan are rather limited. This could lead to convenient interpretations. However, the analysed dataset does not allow definitive conclusions.

In addition, it should be noted that the statistical analysis under consideration takes into account the clustered standard errors. This because the characteristics of each bank are similar for groups of observations within the same cluster (for example total assets). Among the advantages associated with their adoption there is the possibility of 
obtaining smaller standard errors. Consequently, the confidence intervals will be narrower, the test statistics higher and the p-values lower. The latter, among other things, could lead to misleading conclusions.

Table 2. ROAA regression on risk governance variables

\begin{tabular}{|c|c|c|c|c|c|c|c|c|}
\hline & \multicolumn{8}{|c|}{ Dependent variable: } \\
\hline & \multicolumn{4}{|c|}{$\begin{array}{l}\text { Return on Average Assets - ROAA } \\
\text { Pooled OLS Pooled OLS Bank FE } \\
\begin{array}{llll}\text { (1) } & \text { (2) } & \text { (3) } & \text { (4) }\end{array}\end{array}$} & \multicolumn{4}{|c|}{ 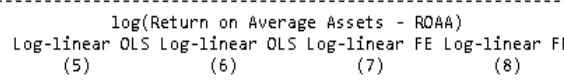 } \\
\hline CRO Present & $\begin{array}{r}-2.1716 * * \\
(0.9033)\end{array}$ & $\begin{array}{l}-0.0842 \\
(0.3473)\end{array}$ & $\begin{array}{l}-0.2294 \\
(0.2687)\end{array}$ & $\begin{array}{l}-0.0275 \\
(0.4039)\end{array}$ & $\begin{array}{c}-4.9936 * * * \\
(1.7205)\end{array}$ & $\begin{array}{l}-0.0918 \\
(0.7785)\end{array}$ & $\begin{array}{l}-1.1542 * * \\
(0.5377)\end{array}$ & $\begin{array}{r}-1.3627 \\
(0.9228)\end{array}$ \\
\hline CRO Executive & $\begin{array}{l}1.9939 * * \\
(0.9136)\end{array}$ & & & & $\begin{array}{l}4.1950^{* *} \\
(1.7304)\end{array}$ & & & \\
\hline CRO TOP 5 & $\begin{array}{c}0.1526 \\
(0.1728)\end{array}$ & & $\begin{array}{c}0.1670 \\
(0.2223)\end{array}$ & & $\begin{array}{l}0.6064 * \\
(0.3171)\end{array}$ & & $\begin{array}{l}1.1454 * * \\
(0.4476)\end{array}$ & \\
\hline CRO Centrality & & $\begin{array}{c}0.2112 \\
(0.4685)\end{array}$ & & $\begin{array}{l}-0.0249 \\
(0.5407)\end{array}$ & & $\begin{array}{c}0.0079 \\
(1.0684)\end{array}$ & & $\begin{array}{c}1.7252 \\
(1.2222)\end{array}$ \\
\hline Risk Committee Experience & $\begin{array}{c}0.1707 \\
(0.4015)\end{array}$ & $\begin{array}{c}0.1284 \\
(0.4678)\end{array}$ & $\begin{array}{l}-0.0825 \\
(0.4475)\end{array}$ & $\begin{array}{l}-0.0478 \\
(0.4225)\end{array}$ & $\begin{array}{l}-0.7870 \\
(0.7402)\end{array}$ & $\begin{array}{l}-0.4441 \\
(1.0232)\end{array}$ & $\begin{array}{c}0.3618 \\
(0.9063)\end{array}$ & $\begin{array}{r}-0.4446 \\
(0.9482)\end{array}$ \\
\hline Active Risk Committee & $\begin{array}{c}0.0142 \\
(0.0092)\end{array}$ & $\begin{array}{l}-0.0033 \\
(0.0044)\end{array}$ & $\begin{array}{c}0.0101 \\
(0.0088)\end{array}$ & $\begin{array}{c}0.0100 \\
(0.0082)\end{array}$ & $\begin{array}{r}0.0464 * * * \\
(0.0173)\end{array}$ & $\begin{array}{l}-0.0023 \\
(0.0094)\end{array}$ & $\begin{array}{r}0.0296 * \\
(0.0172)\end{array}$ & $\begin{array}{r}0.0344 * \\
(0.0179)\end{array}$ \\
\hline Board Independence & $\begin{array}{l}-0.1563 \\
(0.3350)\end{array}$ & $\begin{array}{c}0.2330 \\
(0.3832)\end{array}$ & $\begin{array}{l}-0.3099 \\
(0.4763)\end{array}$ & $\begin{array}{l}-0.3522 \\
(0.4205)\end{array}$ & $\begin{array}{l}-0.1309 \\
(0.6298)\end{array}$ & $\begin{array}{c}0.6866 \\
(0.8520)\end{array}$ & $\begin{array}{l}-1.9630 * * \\
(0.9767)\end{array}$ & $\begin{array}{r}-0.8316 \\
(0.9529)\end{array}$ \\
\hline Bank Size & $\begin{array}{l}0.5587 * * \\
(0.2424)\end{array}$ & $\begin{array}{c}0.0788 \\
(0.1833)\end{array}$ & $\begin{array}{c}0.3212 \\
(0.3408)\end{array}$ & $\begin{array}{c}0.2860 \\
(0.3486)\end{array}$ & $\begin{array}{r}2.0598 * * * \\
(0.4628)\end{array}$ & $\begin{array}{l}0.6693^{*} \\
(0.4029)\end{array}$ & $\begin{array}{l}2.7779 * * * \\
(0.7211)\end{array}$ & $\begin{array}{l}2.9916 * * * \\
(0.8269)\end{array}$ \\
\hline Non Performing Loans/Gross Loans & $\begin{array}{c}-0.0303 * \\
(0.0171)\end{array}$ & $\begin{array}{l}-0.0300 \\
(0.0187)\end{array}$ & $\begin{array}{l}-0.0316 \\
(0.0302)\end{array}$ & $\begin{array}{l}-0.0405 \\
(0.0294)\end{array}$ & $\begin{array}{l}-0.0121 \\
(0.0333)\end{array}$ & $\begin{array}{l}-0.0202 \\
(0.0427)\end{array}$ & $\begin{array}{c}-0.1077 * \\
(0.0620)\end{array}$ & $\begin{array}{r}-0.0795 \\
(0.0687)\end{array}$ \\
\hline Total Capital Ratio & $\begin{array}{c}0.0417 \\
(0.0357)\end{array}$ & & $\begin{array}{c}0.0061 \\
(0.0409)\end{array}$ & & $\begin{array}{c}0.1146 \\
(0.0712)\end{array}$ & & $\begin{array}{r}-0.0036 \\
(0.0923)\end{array}$ & \\
\hline Equity to Asset ratio & $\begin{array}{r}0.1948 * * * \\
(0.0620)\end{array}$ & $\begin{array}{r}0.1966 * * * \\
(0.0638)\end{array}$ & $\begin{array}{l}0.2584 * \\
(0.1366)\end{array}$ & $\begin{array}{r}0.2826 * * * \\
(0.1018)\end{array}$ & $\begin{array}{r}0.4538 * * * \\
(0.1251)\end{array}$ & $\begin{array}{r}0.4562^{* * *} \\
(0.1456)\end{array}$ & $\begin{array}{l}0.7096 * * \\
(0.3175)\end{array}$ & $\begin{array}{l}0.7957 * * * \\
(0.2511)\end{array}$ \\
\hline Net Interest Margin & $\begin{array}{c}0.3139 \\
(0.2746)\end{array}$ & $\begin{array}{l}-0.0518 \\
(0.2297)\end{array}$ & $\begin{array}{c}0.2420 \\
(0.4391)\end{array}$ & $\begin{array}{c}0.1333 \\
(0.3975)\end{array}$ & $\begin{array}{l}-0.5816 \\
(0.5135)\end{array}$ & $\begin{array}{c}-0.8456 * \\
(0.4990)\end{array}$ & $\begin{array}{c}1.1785 \\
(0.9137)\end{array}$ & $\begin{array}{c}0.2085 \\
(0.9366)\end{array}$ \\
\hline Cost to Income ratio & $\begin{array}{c}-0.0250 * * * \\
(0.0059)\end{array}$ & $\begin{array}{c}-0.0255 * * * \\
(0.0046)\end{array}$ & $\begin{array}{c}-0.0363^{* * *} \\
(0.0067)\end{array}$ & $\begin{array}{c}-0.0342 * * * \\
(0.0062)\end{array}$ & $\begin{array}{c}-0.0903 * * * \\
(0.0131)\end{array}$ & $\begin{array}{c}-0.0876 * * * \\
(0.0141)\end{array}$ & $\begin{array}{c}-0.1073 * * * \\
(0.0171)\end{array}$ & $\begin{array}{c}-0.0966 * * * \\
(0.0172)\end{array}$ \\
\hline Net Loans/Deposit & $\begin{array}{c}0.0026 \\
(0.0081)\end{array}$ & $\begin{array}{l}-0.0089 \\
(0.0091)\end{array}$ & $\begin{array}{c}0.0109 \\
(0.0103)\end{array}$ & $\begin{array}{c}0.0081 \\
(0.0095)\end{array}$ & $\begin{array}{l}0.0280 * \\
(0.0150)\end{array}$ & $\begin{array}{c}0.0131 \\
(0.0206)\end{array}$ & $\begin{array}{l}0.0677 * * * \\
(0.0212)\end{array}$ & $\begin{array}{c}0.0234 \\
(0.0219)\end{array}$ \\
\hline Liquid Assets/Deposit & $\begin{array}{c}0.0058 \\
(0.0041)\end{array}$ & & $\begin{array}{c}0.0026 \\
(0.0040)\end{array}$ & & $\begin{array}{c}0.0028 \\
(0.0079)\end{array}$ & & $\begin{array}{r}-0.0071 \\
(0.0081)\end{array}$ & \\
\hline Constant & $\begin{array}{r}-8.1660 * * \\
(3.9794)\end{array}$ & $\begin{array}{c}0.5495 \\
(3.1727)\end{array}$ & & & $\begin{array}{c}-28.6713 * * * \\
(7.7271)\end{array}$ & $\begin{array}{l}-6.9538 \\
(7.0103)\end{array}$ & & \\
\hline observations & 35 & 35 & 35 & 35 & 31 & 31 & 31 & 31 \\
\hline R2 & 0.8863 & 0.8368 & 0.9023 & 0.8950 & 0.9274 & 0.8519 & 0.9030 & 0.8586 \\
\hline Adjusted R2 & 0.8066 & 0.7587 & 0.7785 & 0.7901 & 0.8639 & 0.7662 & 0.7355 & 0.6737 \\
\hline F Statistic & $11.1313^{* * * *}$ & $10.7183^{*} * *$ & $10.6543^{* * *} *$ & $13.1782 * * *$ & $14.5987 * * *$ & 9. $9394 * * * *$ & $7.8778 * * *$ & $7.1776 * * *$ \\
\hline
\end{tabular}

The table shows OLS regressions (columns 1, 2, 5, 6) and fixed effect regressions (columns 3, 4, 7, 8) of return on average assets (ROAA) on risk governance and control variables. The specification in columns 5, 6, 7, 8 uses the natural logarithm of the dependent variable. The coefficient on the constant term in columns 3, 4, 7, 8 is omitted because in fixed effects model the intercept is different for each bank. The number of observations for risk-adjusted performance and performance variables is lower for log-linear models (31) than for linear models (35), as the sign of some ROAA observations is negative. Columns vary by the regressors they include. The Eurozone's Global Systemically Important Banks (G-SIBs) are taken into consideration, over the period 2014-2018. Absolute values of robust t-statistics are in brackets. The asterisks denote the significance level of the coefficients at $10 \%(*), 5 \%(* *)$ and $1 \%(* * *)$.

From the tables representative of the results of the analysis (Tables 2 to 6), it emerges that the output of the $\mathrm{R}$ software of the regressions with fixed effects does not generate any intercepts $\alpha$. The reason is attributable to the structure of the fixed effects model. In fact, in it the intercept is different for each bank, although the $\beta$ coefficient remains the same.

Regarding the inferential analysis, we observe that the CRO Present variable usually expresses a negative impact on profitability. In essence, the presence of the CRO is associated with a negative change in the profitability indicators 
(risk-adjusted and not risk-adjusted) and, on the other hand, with a positive change in the Z-score. Vice versa, when the CRO is a member of the executive committee (CRO Executive) the signs of the relationships are inverse with respect to those of the previous case. Therefore, this role of the CRO affects the bank's propensity to take risks. In particular, the signs of the coefficients of this variable are positive when the performance indicators are regressed, and negative when the Z-score is regressed.

Like the CRO Executive variable, the CRO Top 5 variable usually has a positive impact on profitability and a negative effect on the Z-score, despite having lower regression coefficient values.

The CRO Centrality variable, on the other hand, does not seem to have a significant relationship with both profitability and Z-score measures.

The financial expertise of the Risk committee members (measured by the Risk Committee Experience variable) should, in principle, lead to contain the overall level of risk assumed by the banks. However, our results do not seem to lead to such conclusions.

Furthermore, the board directors' independence (measured by Board Independence variable) does not seem to play a significant role in the profitability of the banks analysed. This does not comfort the policy of several banking supervisory authorities aimed at promoting an ever greater independence of this body.

As regards, however, the control variables, it emerges that the size of the bank, in terms of assets (Bank Size) and in terms of level of capitalization (Total Capital ratio), is associated with positive changes in profitability indicators. Conversely, the Cost to Income ratio is associated with negative changes in all the profitability indicators considered.

Moreover, it is important to highlight how, in principle, the log-linear model is more suitable for explaining the dependence between the independent variables and the dependent variables, especially in the case of risk-adjusted profitability indicators and the Z-score.

However, with reference to the analysis of profitability in terms of ROAA, from the values represented in Table 2 it emerges that the log-linear model does not improve the estimate of adjusted $\mathrm{R}^{2}$. This especially if we consider the fixed effects model. The same happens for ROAE (Table 3). For these dependent variables, this consideration supports the hypothesis of a linear dependence. 
Table 3. ROAE regression on risk governance variables

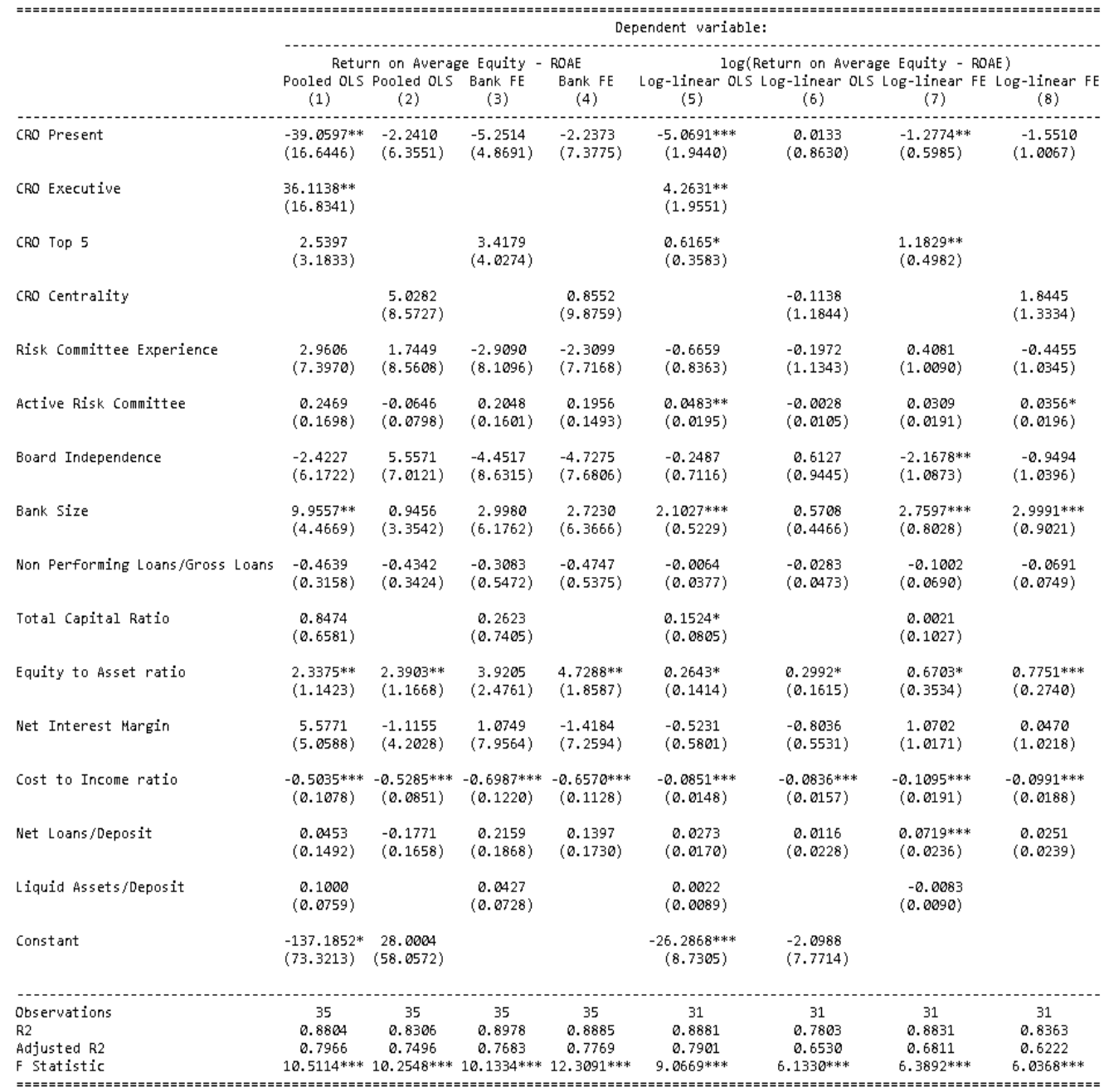

The table shows OLS regressions (columns 1, 2, 5, 6) and fixed effect regressions (columns 3, 4, 7, 8) of return on average equity (ROAE) on risk governance and control variables. The specification in columns $5,6,7,8$ uses the natural logarithm of the dependent variable. The coefficient on the constant term in columns 3, 4, 7, 8 is omitted because in fixed effects model the intercept is different for each bank. The number of observations for risk-adjusted performance and performance variables is lower for log-linear models (31) than for linear models (35), as the sign of some ROAE observations is negative. Columns vary by the regressors they include. The Eurozone's Global Systemically Important Banks (G-SIBs) are taken into consideration, over the period 2014-2018. Absolute values of robust t-statistics are in brackets. The asterisks denote the significance level of the coefficients at $10 \%(*), 5 \%(* *)$ and $1 \%(* * *)$.

With reference to the risk-adjusted profitability indicators (RAROAE and RAROAA), the log-linear regression achieves a significant improvement in terms of goodness of the model. This improvement is even more marked when considering the pooled OLS model (Tables 4 and 5). This evidence therefore supports the hypothesis of a non-linear dependence. 
Table 4. RAROAA regression on risk governance variables

\begin{tabular}{|c|c|c|c|c|c|c|c|c|}
\hline & \multicolumn{8}{|c|}{ Dependent variable: } \\
\hline & $\begin{array}{l}\text { Risk Adjus } \\
\text { Pooled OLS } \\
\text { (1) }\end{array}$ & $\begin{array}{l}\text { sted Return on } \\
\text { Pooled OLS } \\
\text { (2) }\end{array}$ & $\begin{array}{c}\text { Average Assets } \\
\text { Bank FE } \\
\text { (3) }\end{array}$ & $\begin{array}{c}\text { - RAROAAA } \\
\text { Bank FE } \\
\text { (4) }\end{array}$ & $\begin{array}{l}\log (\text { Risk Adju } \\
\text { Log-linear OLS } \\
\text { (5) }\end{array}$ & $\begin{array}{l}\text { usted Return on } \\
\text { Log-linear oLS } \\
\text { (6) }\end{array}$ & $\begin{array}{l}\text { Average Assets } \\
\text { Log-linear FE } \\
\text { (7) }\end{array}$ & 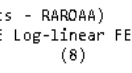 \\
\hline CRO Present & $\begin{array}{l}-1.9995 * \\
(1.0620)\end{array}$ & $\begin{array}{r}-0.0857 \\
(0.3800)\end{array}$ & $\begin{array}{r}-0.1498 \\
(0.3158)\end{array}$ & $\begin{array}{l}-0.0481 \\
(0.4631)\end{array}$ & $\begin{array}{c}-9.2416 * * * * \\
(2.7450)\end{array}$ & $\begin{array}{l}-0.4557 \\
(1.4086)\end{array}$ & $\begin{array}{l}-1.1542 * * \\
(0.5377)\end{array}$ & $\begin{array}{r}-1.3627 \\
(0.9228)\end{array}$ \\
\hline CRO Executive & $\begin{array}{c}1.7659 \\
(1.0741)\end{array}$ & & & & $\begin{array}{r}7.6565 * * * \\
(2.7608)\end{array}$ & & & \\
\hline CRO TOP 5 & $\begin{array}{c}0.1699 \\
(0.2031)\end{array}$ & & $\begin{array}{c}0.0643 \\
(0.2612)\end{array}$ & & $\begin{array}{r}1.4253 * * * \\
(0.5059)\end{array}$ & & $\begin{array}{l}1.1454 * * \\
(0.4476)\end{array}$ & \\
\hline CRO Centrality & & $\begin{array}{c}0.1163 \\
(0.5126)\end{array}$ & & $\begin{array}{l}-0.0276 \\
(0.6199)\end{array}$ & & $\begin{array}{c}0.5169 \\
(1.9332)\end{array}$ & & $\begin{array}{c}1.7252 \\
(1.2222)\end{array}$ \\
\hline Risk Committee Experience & $\begin{array}{c}0.2634 \\
(0.4719)\end{array}$ & $\begin{array}{c}0.2768 \\
(0.5119)\end{array}$ & $\begin{array}{c}0.0600 \\
(0.5260)\end{array}$ & $\begin{array}{c}0.0084 \\
(0.4844)\end{array}$ & $\begin{array}{c}0.6683 \\
(1.1809)\end{array}$ & $\begin{array}{l}1.1584 \\
(1.8514)\end{array}$ & $\begin{array}{c}0.3618 \\
(0.9063)\end{array}$ & $\begin{array}{r}-0.4446 \\
(0.9482)\end{array}$ \\
\hline Active Risk Committee & $\begin{array}{c}0.0125 \\
(0.0108)\end{array}$ & $\begin{array}{r}-0.0043 \\
(0.0048)\end{array}$ & $\begin{array}{c}0.0048 \\
(0.0104)\end{array}$ & $\begin{array}{c}0.0065 \\
(0.0094)\end{array}$ & $\begin{array}{l}0.0529 * \\
(0.0275)\end{array}$ & $\begin{array}{r}-0.0398 * * \\
(0.0171)\end{array}$ & $\begin{array}{c}0.0296 * \\
(0.0172)\end{array}$ & $\begin{array}{r}0.0344 * \\
(0.0179)\end{array}$ \\
\hline Board Independence & $\begin{array}{l}-0.1007 \\
(0.3938)\end{array}$ & $\begin{array}{c}0.2061 \\
(0.4193)\end{array}$ & $\begin{array}{r}-0.3400 \\
(0.5599)\end{array}$ & $\begin{array}{l}-0.3540 \\
(0.4821)\end{array}$ & $\begin{array}{l}-0.0483 \\
(1.0848)\end{array}$ & $\begin{array}{c}1.4777 \\
(1.5417)\end{array}$ & $\begin{array}{l}-1.9630^{* * *} \\
(0.9767)\end{array}$ & $\begin{array}{r}-0.8316 \\
(0.9529)\end{array}$ \\
\hline Bank Size & $\begin{array}{l}0.4852 * \\
(0.2850)\end{array}$ & $\begin{array}{c}0.0584 \\
(0.2005)\end{array}$ & $\begin{array}{c}0.4343 \\
(0.4006)\end{array}$ & $\begin{array}{c}0.3987 \\
(0.3996)\end{array}$ & $\begin{array}{r}3.1455 * * * \\
(0.7383)\end{array}$ & $\begin{array}{c}0.6973 \\
(0.7289)\end{array}$ & $\begin{array}{l}2.7779 * * * \\
(0.7211)\end{array}$ & $\begin{array}{l}2.9916 * * * \\
(0.8269)\end{array}$ \\
\hline Non Performing Loans/Gross Loans & $\begin{array}{l}-0.0153 \\
(0.0201)\end{array}$ & $\begin{array}{r}-0.0146 \\
(0.0205)\end{array}$ & $\begin{array}{r}-0.0365 \\
(0.0355)\end{array}$ & $\begin{array}{l}-0.0352 \\
(0.0337)\end{array}$ & $\begin{array}{l}0.1055 * * \\
(0.0532)\end{array}$ & $\begin{array}{l}0.1444 * \\
(0.0772)\end{array}$ & $\begin{array}{l}-0.1077 * \\
(0.0620)\end{array}$ & $\begin{array}{r}-0.0795 \\
(0.0687)\end{array}$ \\
\hline Total Capital Ratio & $\begin{array}{c}0.0292 \\
(0.0420)\end{array}$ & & $\begin{array}{r}-0.0247 \\
(0.0480)\end{array}$ & & $\begin{array}{c}0.0714 \\
(0.1136)\end{array}$ & & $\begin{array}{r}-0.0036 \\
(0.0923)\end{array}$ & \\
\hline Equity to Asset ratio & $\begin{array}{r}0.2050 * * * \\
(0.0729)\end{array}$ & $\begin{array}{l}0.2001 * * * \\
(0.0698)\end{array}$ & $\begin{array}{r}0.2775 * \\
(0.1606)\end{array}$ & $\begin{array}{l}0.2265 * \\
(0.1167)\end{array}$ & $\begin{array}{r}0.8902 * * * \\
(0.1996)\end{array}$ & $\begin{array}{r}0.7579 * * * \\
(0.2635)\end{array}$ & $\begin{array}{l}0.7096 * * \\
(0.3175)\end{array}$ & $\begin{array}{l}0.7957 * * * \\
(0.2511)\end{array}$ \\
\hline Net Interest Margin & $\begin{array}{c}0.1673 \\
(0.3228)\end{array}$ & $\begin{array}{r}-0.0842 \\
(0.2513)\end{array}$ & $\begin{array}{c}0.1854 \\
(0.5161)\end{array}$ & $\begin{array}{c}0.1928 \\
(0.4557)\end{array}$ & $\begin{array}{c}0.0917 \\
(0.8192)\end{array}$ & $\begin{array}{c}0.1845 \\
(0.9029)\end{array}$ & $\begin{array}{c}1.1785 \\
(0.9137)\end{array}$ & $\begin{array}{c}0.2085 \\
(0.9366)\end{array}$ \\
\hline Cost to Income ratio & $\begin{array}{l}-0.0093 \\
(0.0069)\end{array}$ & $\begin{array}{l}-0.0086 * \\
(0.0051)\end{array}$ & $\begin{array}{c}-0.0219 * * * \\
(0.0079)\end{array}$ & $\begin{array}{c}-0.0207 * * * \\
(0.0071)\end{array}$ & $\begin{array}{c}-0.0582 * * * \\
(0.0209)\end{array}$ & $\begin{array}{l}-0.0458 * \\
(0.0256)\end{array}$ & $\begin{array}{c}-0.1073 * * * \\
(0.0171)\end{array}$ & $\begin{array}{c}-0.0966 * * * \\
(0.0172)\end{array}$ \\
\hline Net Loans/Deposit & $\begin{array}{c}0.0022 \\
(0.0095)\end{array}$ & $\begin{array}{r}-0.0061 \\
(0.0099)\end{array}$ & $\begin{array}{c}0.0080 \\
(0.0121)\end{array}$ & $\begin{array}{c}0.0080 \\
(0.0109)\end{array}$ & $\begin{array}{c}0.0337 \\
(0.0240)\end{array}$ & $\begin{array}{c}0.0143 \\
(0.0372)\end{array}$ & $\begin{array}{l}0.0677 * * * \\
(0.0212)\end{array}$ & $\begin{array}{c}0.0234 \\
(0.0219)\end{array}$ \\
\hline Liquid Assets/Deposit & $\begin{array}{c}0.0040 \\
(0.0048)\end{array}$ & & $\begin{array}{c}0.0009 \\
(0.0047)\end{array}$ & & $\begin{array}{l}-0.0031 \\
(0.0126)\end{array}$ & & $\begin{array}{r}-0.0071 \\
(0.0081)\end{array}$ & \\
\hline Constant & $\begin{array}{l}-8.1594 * \\
(4.6781)\end{array}$ & $\begin{array}{r}-0.8847 \\
(3.4713)\end{array}$ & & & $\begin{array}{c}-52.1175 * * * \\
(12.3282)\end{array}$ & $\begin{array}{r}-17.5321 \\
(12.6847)\end{array}$ & & \\
\hline $\begin{array}{l}\text { Observations } \\
\text { R2 } \\
\text { Adjusted R2 } \\
\text { F Statistic }\end{array}$ & $\begin{array}{c}35 \\
0.5757 \\
0.2787 \\
1.9386 *\end{array}$ & $\begin{array}{l}\quad 35 \\
0.4726 \\
0.22284 \\
1.8737 *\end{array}$ & $\begin{array}{c}35 \\
0.7636 \\
0.4642 \\
3.7270 * * *\end{array}$ & $\begin{array}{c}35 \\
0.7584 \\
0.5168 \\
4.8518 * * *\end{array}$ & $\begin{array}{c}31 \\
0.9101 \\
0.8315 \\
11.5735 * * *\end{array}$ & $\begin{array}{c}31 \\
0.7643 \\
0.6278 \\
5.6001 * * *\end{array}$ & $\begin{array}{c}31 \\
0.9030 \\
0.7355 \\
7.8778 * * *\end{array}$ & $\begin{array}{c}31 \\
0.8586 \\
0.6737 \\
7.1776 * * *\end{array}$ \\
\hline
\end{tabular}

The table shows OLS regressions (columns 1, 2, 5, 6) and fixed effect regressions (columns 3, 4, 7, 8) of risk-adjusted return on average assets (RAROAA) on risk governance and control variables. The specification in columns 5, 6, 7, 8 uses the natural logarithm of the dependent variable. The coefficient on the constant term in columns 3, 4, 7, 8 is omitted because in fixed effects model the intercept is different for each bank. The number of observations for risk-adjusted performance and performance variables is lower for log-linear models (31) than for linear models (35), as the sign of some RAROAA observations is negative. Columns vary by the regressors they include. The Eurozone's Global Systemically Important Banks (G-SIBs) are taken into consideration, over the period 2014-2018. Absolute values of robust t-statistics are in brackets. The asterisks denote the significance level of the coefficients at $10 \%(*), 5 \%(* *)$ and $1 \%(* * *)$. 
Table 5. RAROAE regression on risk governance variables

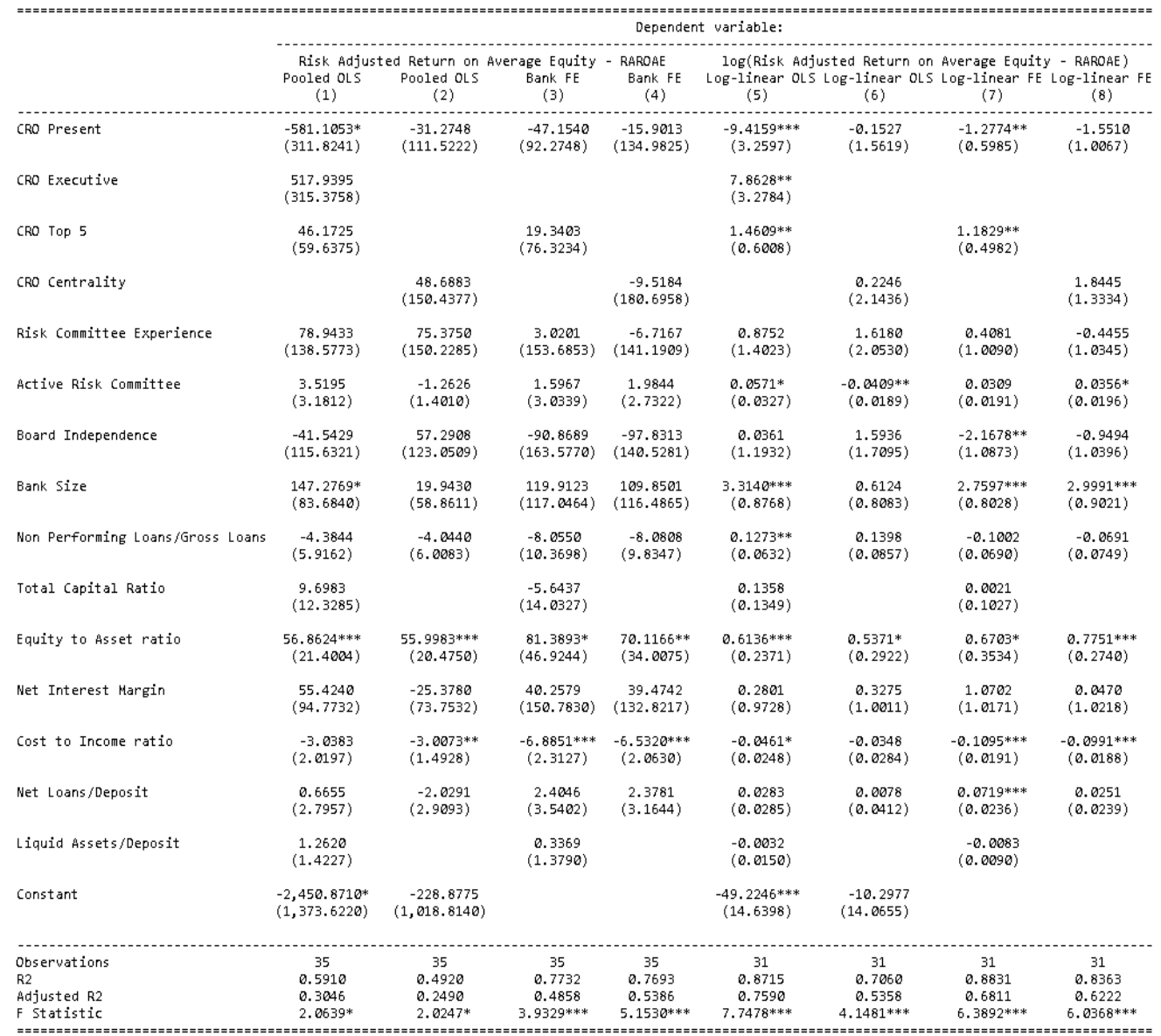

The table shows OLS regressions (columns 1, 2, 5, 6) and fixed effect regressions (columns 3, 4, 7, 8) of risk-adjusted return on average equity (RAROAE) on risk governance and control variables. The specification in columns 5, 6, 7, 8 uses the natural logarithm of the dependent variable. The coefficient on the constant term in columns 3, 4, 7, 8 is omitted because in fixed effects model the intercept is different for each bank. The number of observations for risk-adjusted performance and performance variables is lower for log-linear models (31) than for linear models (35), as the sign of some RAROAE observations is negative. Columns vary by the regressors they include. The Eurozone's Global Systemically Important Banks (G-SIBs) are taken into consideration, over the period 2014-2018. Absolute values of robust $t$-statistics are in brackets. The asterisks denote the significance level of the coefficients at $10 \%(*), 5 \%(* *)$ and $1 \%(* * *)$.

Table 6 shows that the log-linear model is able of better capturing the dependence between the independent variables and the Z-score. In particular, the non-linear dependence is more pronounced in the case of the fixed effects model than in the pooled OLS model. By contrast, the pooled OLS model does not show an improvement in terms of adjusted $\mathrm{R}^{2}$ when switching to the log-linear model. 
Table 6. Z-score regression on risk governance variables

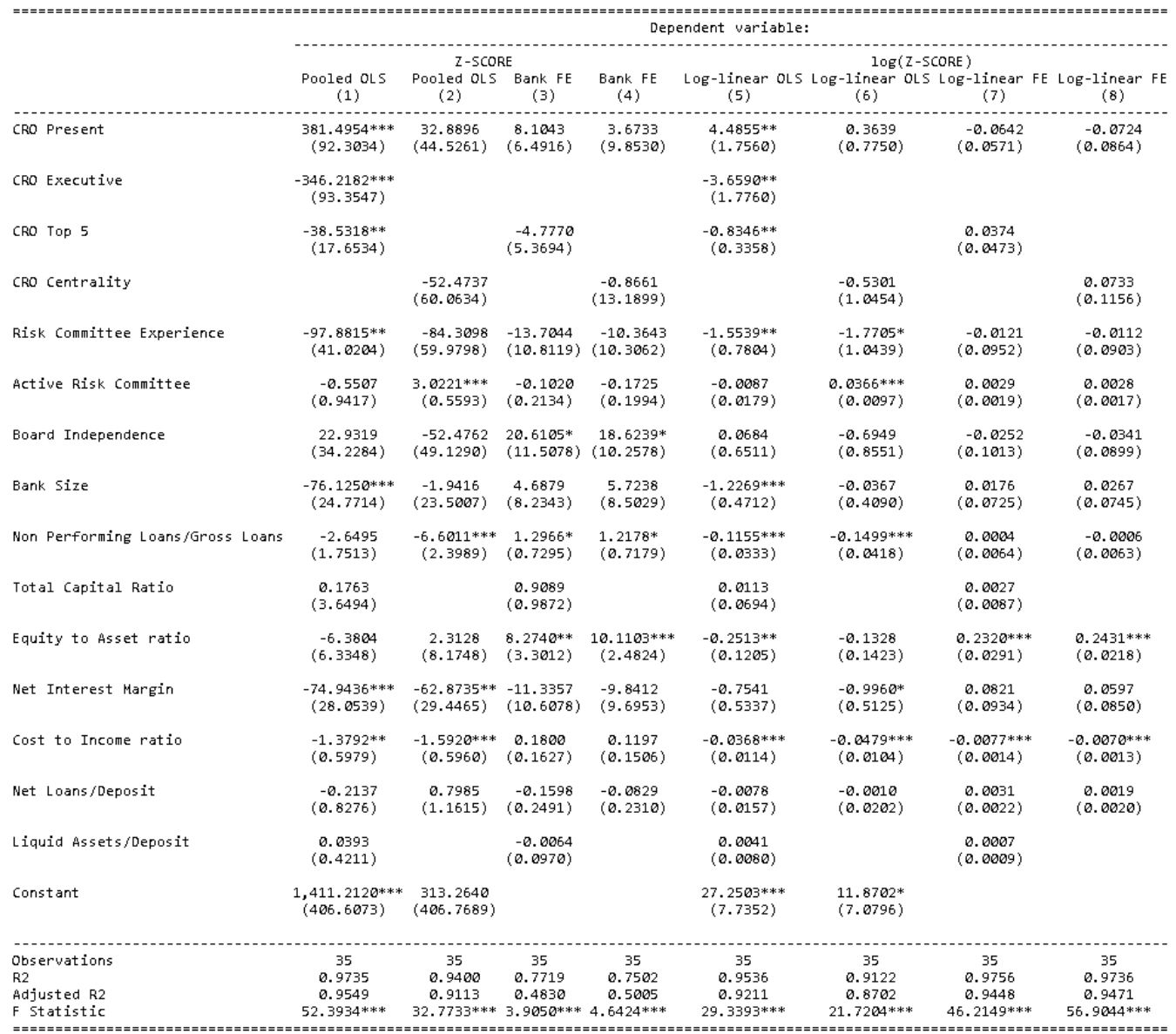

The table shows OLS regressions (columns 1, 2, 5, 6) and fixed effect regressions (columns 3, 4, 7, 8) of Z-score on risk governance and control variables. The Z-score represents a particular non-linear transformation of the bank's probability of default. The specification in columns $5,6,7,8$ uses the natural logarithm of the dependent variable. The coefficient on the constant term in columns $3,4,7,8$ is omitted because in fixed effects model the intercept is different for each bank. Columns vary by the regressors they include. The Eurozone's Global Systemically Important Banks (G-SIBs) are taken into consideration, over the period 2014-2018. Absolute values of robust t-statistics are in brackets. The asterisks denote the significance level of the coefficients at $10 \%(*), 5 \%(* *)$ and $1 \%(* * *)$.

Finally, it should be noted that column 2 of Table 6 allows to detect the existence of a robust positive relationship between the Active Risk Committee and the Z-score. Specifically, as the number of meetings increases, the value of the Z-score increases and consequently the overall corporate solidity improves. A more intense activity of the Risk committee would allow it to define strategic lines that can be reflected in an improvement in corporate risk monitoring. Hence, a particularly active Risk committee may be able to counteract the natural tendency of banks to take excessive risks. This result is consistent with the thesis that a solid risk management function can reduce the overall risk (Ellul and Yerramilli 2013; Lingel and Sheedy 2012).

\section{Conclusion}

The research investigates whether and how risk governance is able to affect banks' performance. This subject matter is poorly explored by the literature on corporate governance of credit institutions, mainly because of the presence of qualitative information that cannot easily be transformed into quantitative data. Furthermore, the existing scientific literature has not yet provided unanimous results.

Research on the subject focus mainly on the U.S. banking system and often consider the period of the international financial crisis. This study, however, focuses on the Eurozone's Global Systemically Important Banks, over the period 2014-2018. 
Specifically, some variables being analysed show elements of connection between risk governance, on the one hand, and bank performance, on the other.

However, it must be considered that both the sample of banks and the time span are rather limited. Therefore, the analysed dataset does not allow to reach definitive conclusions.

Consistent with the study published by Ellul and Yerramilli (2013) and Lingel and Sheedy (2012), we find that stronger risk management is able to counter the natural tendency of banks to assume high levels of financial risks.

With particular regard to the role covered by the Chief Risk Officer, the statistical analysis shows that its presence within the banking organization can contribute to reduce bank risk captured by the Z-score indicator. However, this has a negative impact on profitability, both risk-adjusted and not risk-adjusted.

With reference to the importance attributed by the bank to the CRO - in terms of membership of the executive committee (CRO Executive) and in terms of remuneration received compared to that of the other top managers (CRO Top 5) - the results highlight how these variables are positively correlated to both profitability and bank risk-taking.

Furthermore, among the risk governance variables, the Active risk Committee variable assumes considerable importance. In fact, as the number of meetings of this Committee increases, the value of the Z-score increases and, consequently, the bank's overall solidity improves.

In conclusion, the results of this research underline the importance of well-structured, efficient and effective bank risk governance, given the existence of dependency links with profitability and risks.

\section{References}

Adams, R. B., \& Mehran, H. (2012). Bank board structure and performance: Evidence for large bank holding companies. Journal of Financial Intermediation, 21(2), 243-267.

Aebi, V., Sabato, G., \& Schmid, M. (2012). Risk management, corporate governance, and bank performance in the financial crisis. Journal of Banking \& Finance, 36, 3213-3226.

Battaglia, F., \& Gallo, A. (2015). Risk governance and Asian bank performance: An empirical investigation over the financial crisis. Emerging Markets Review, 25, 53-68.

Battaglia, F., \& Gallo, A. (2017). Strong boards, ownership concentration and EU banks' systemic risk-taking: Evidence from the financial crisis. Journal of International Financial Markets, Institutions \& Money, 46, 128-146.

Boyd, J. H., \& Graham, S. L. (1986). Risk, Regulation, and Bank Holding Company Expansion into Nonbanking, Federal Reserve Bank of Minneapoli. Quarterly Review, 10(2), 2-17.

Boyd, J. H., Graham, S. L., \& Hewitt, R. S. (1993). Bank holding company mergers with nonbank financial firms: effects on the risk of failure. Journal of Banking \& Finance, (17), 43-63.

Brandão-Marques, L., \& Oppers, S. E. (2014). Risk taking by banks: The role of governance and executive pay. Chapter 3 by "Global financial stability report: Risk taking, liquidity and shadow banking - Curbing excess while promoting growth" International Monetary Fund, October 2014.

Dong, Y., Meng, C., Firth, M., \& Hou, W. (2014). Ownership structure and risk-taking: Comparative evidence from private and state-controlled banks in China. International Review of Financial Analysis, 36, 120-130.

Dupire, M., \& Slagmulder, R. (2019). Risk governance of financial institutions: The effect of ownership structure and board independence. Finance Research Letters, 28, 227-237.

Ellul, A., \& Yerramilli, V. (2013). Stronger Risk Controls, Lower Risk: Evidence from U.S. Bank Holding Companies. The Journal of Finance, LXVIII(5), 1757-1803.

Erkens, D. H., Hung, M., \& Matos, P. (2012). Corporate Governance in the 2007-2008 Financial Crisis: Evidence from Financial Institutions Worldwide. Journal of Corporate Finance, 18(2), 389-411.

Financial Stability Board (FSB). (2013). Thematic Review on Risk Governance. Peer Review Report. Retrieved from www.fsb.org/wp-content/uploads/r_130212.pdf

Harkin, S. M., Mare, D. S., \& Crook, J. N. (2013). Independence in bank governance structure: Empirical evidence of effects on bank risk and performance. Research in International Business and Finance, 53, 1-21.

Laeven, L., \& Levine, R. (2009). Bank Governance, Regulation, and Risk Taking. Journal of Financial Economics, 93(2), 259-275. 
Lingel, A., \& Sheedy, E. (2012). The Influence of Risk Governance on Risk Outcomes. Macquarie Applied Finance Centre, Research Paper n. 37, November 2012. Retrieved from http://ssrn.com/abstract=2187116

Minton, B. A., Taillard, J. P., \& Williamson, R. (2014, April). Financial Expertise of the Board, Risk Taking, and Performance: Evidence from Bank Holding Companies. Journal of Financial and Quantitative Analysis, 49(2), 351-380.

Mongiardino, A., \& Plath, C. (2010). Risk governance at large banks: Have any lessons been learned?. Journal of Risk management in Financial Institutions, 3(2), 116-123.

Organisation for Economic Co-operation and Development (OECD). (2003). Experiences from the Regional $\begin{array}{lllll}\text { Corporate } & \text { Governance } & \text { Roundtables. } & \text { OECD } & \text { (Ed.). }\end{array}$ www.oecd.org/daf/ca/corporategovernanceprinciples/ 23742340.pdf

Pathan, S. (2009). Strong board, CEO power and bank risk-taking. Journal of Banking \& Finance, 33(7), 1340-1350.

Pathan, S., \& Faff, R. (2013). Does board structure in banks really affect their performance?. Journal of Banking \& Finance, 37, 1573-1589.

Stiroh, K. J. (2004, October). Diversification in Banking: Is Noninterest Income the Answer?. Journal of Money, Credit and Banking, 36(5), 853-882.

Stiroh, K. J., \& Rumble, A. (2006). The dark side of diversification: The case of US financial holding companies. Journal of Banking \& Finance, 30(8), 2131-2161.

\section{Notes}

Note 1. The Bank Size variable, equal to the natural logarithm of the total assets, is used to verify any differences regarding the performance between banks belonging to different size classes (Aebi et al. 2012, p. 3218).

Note 2. The Eurozone's Global Systemically Important Banks (G-SIBs) over the period 2014-2018 are: Banco Santander SA; BNP Paribas SA; Crédit Agricole SA; Deutsche Bank AG; Ing Bank NV; Société Générale; Unicredit SpA.

Note 3. Interbank ratio is money lent to other banks divided by money borrowed from other banks.

\section{Copyrights}

Copyright for this article is retained by the author(s), with first publication rights granted to the journal.

This is an open-access article distributed under the terms and conditions of the Creative Commons Attribution license (http://creativecommons.org/licenses/by/4.0/). 